\title{
UM DESPERTAR PARA OS SENTIDOS DA ADOLESCÊNCIA
}

LACADÉE, P. O despertar e o exílio: ensinamentos psicanaliticos da mais delicada das transições, a adolescência. Rio de Janeiro: Contra Capa Livraria, 2011.

Século XIX, reforça-se o interesse das famílias em controlar os jovens. Contudo, contrastando com esse anseio de calma, a juventude se rebela e ameaça a ordem estabelecida. Os gestos e discursos, ambos inflamados, evidenciam a importância da sexualidade, que "[...] leva [o jovem] para longe de sua família, o atrai para outro lugar. Eis $O$ despertar da primavera (WEDEKIND, 1891) "1" (LACADÉE, 2011, p. 17). É com referência ao escritor que Philippe Lacadée dá início ao percurso no qual, com a contribuição da teoria psicanalítica, pretende nos apresentar o que, de fato, está em jogo na conduta dos adolescentes. Psicanalista e membro da École de La Cause Freudienne, da Associação Mundial de Psicanálise e do Centre Interdisciplinaire sur l'Enfant (CIEN), Lacadée explora com propriedade os meandros dessa que compreende como a mais delicada das transições.

Escritores e poetas continuam a acompanhá-lo ao longo de toda a obra: Rimbaud (1854-1891), Hölderlin (1770-1843), Rousseau (1712-1778), Musil (1880-1942) são autores que, segundo Lacadée (2011, p. 159), “[...] precederam a descoberta de Freud e testemunharam esse momento em que o romance familiar se engancha em outra lógica [...]”. A adolescência já surgia, na pena desses autores, como uma transição em que algo novo se inaugura. Representantes, em sua própria trajetória de vida, dessa passagem, seus escritos permitiram também a Lacadée demonstrar a importância do uso da língua como saída para o tratamento desse impossível que se apodera

\footnotetext{
*Doutoranda em Educação pela Universidade Federal de Minas Gerais (UFMG); Psicanalista e Professora da Pontifícia Universidade Católica (PUC/Minas). E-mail: marialice@ig.com.br
} 
do jovem adolescente. Ao longo da obra entendemos como a palavra e seus usos se constituem em uma via que permite recolocar, por um novo trilhamento significante, o corpo pulsante do adolescente nos caminhos do desejo.

Abordando a adolescência sob a perspectiva da psicanálise, Lacadée inicia por colocar-nos diante dos impasses experimentados pelos adolescentes enquanto efeitos do encontro do sujeito com o desejo sexual. Pergunta-se:

Como o adolescente lidará com isso? Qual será sua margem de manobra entre os sobressaltos que surgem e a herança de sua infância? Arriscará toda sua vida ou saberá consentir com o sacrifício de uma parte de gozo que aí se mostra em jogo? (LACADÉE, 2011, p. 28).

Com essas questões, apresenta-nos um cenário em que o despertar do corpo coloca o sujeito diante de um real insuportável que pode levar ao desprezo ou ódio de si como resposta. Nesse momento é que têm lugar as condutas de risco que o autor compreende como "[...] solicitações simbólicas da morte na busca de limites, tentativas desajeitadas e dolorosas de se situar no mundo [...]" (LACADÉE, 2011, p. 57), contrariando as teses que entendem as fugas, errâncias e até mesmo as tentativas de suicídio dos adolescentes como distúrbios de comportamento. Lacadée propõe, dessa forma, uma análise que coloca sob outro prisma os comportamentos comuns entre os adolescentes.

O encontro com o outro sexo, ou encontro com a diferença sexual, constitui-se, para Lacadée, na raiz das condutas de risco nas quais se aventura o adolescente. Trata-se do encontro do sujeito com o vazio, com a falta de um saber constituído que o oriente quanto ao que fazer com a pulsão. Com argumentos contundentes, demonstra que não é sem razão que essas condutas ocorrem, pois, nesse momento, o sujeito se depara com a experiência de um exílio.

Para além do Despertar da primavera a experiência da adolescência implica, necessariamente, num exílio. Lacadée nos demonstra, valendo-se da psicanálise, bem como dos textos literários que lhe servem de referência, que o adolescente experimenta, além do exílio da natureza - fundamental e inerente a todo sujeito, decorrente de sua condição de ser na linguagem -, o exílio próprio da adolescência. Em suas palavras, “[...] devido ao real da puberdade, o sujeito é exilado de seu corpo de criança e das palavras de 
sua infância, sem poder dizer o que lhe acontece [...]" (LACADÉE, 2011, p. 75). Trata-se de uma solidão de difícil tradução e que exige, de cada sujeito, a invenção de um modo próprio de dar nome ao que lhe acontece. As palavras e nomes da infância já não servem mais e as que podem vir a nomear as transformações que experimenta ainda não foram inventadas.

Ao longo do texto, o autor de $O$ despertar e o exílio introduz, aqui e ali, indicações preciosas para quem recorrer à sua leitura em busca de referências que possam contribuir para o manejo da clínica com adolescentes. A adolescência exige que o sujeito invente novas formas de laço para seguir em frente. "O amor a que tinha acesso, até então naturalmente, por ser filho de seus pais, mostra-se então sob outra luz, cabendo-lhe a responsabilidade de inventá-lo em outro lugar [...]" (LACADÉE, 2011, p. 158). Lacadée preocupa-se em fortalecer a concepção, já reconhecida pelos psicanalistas, de que esse processo de invenção se dá, fundamentalmente, através da língua. A companhia permanente dos escritores ao longo de toda a obra permite-nos, mais do que compreender, experimentar os efeitos da língua e seus usos como fundamentais para a vivência dessa transição. É através do uso da língua que o sujeito adolescente pode inventar um lugar para si e novas formas de laço com o outro. A adolescência, afirma o autor,

[...] por estar ligada a algo do 'desregramento de todos os sentidos', [expressão que o autor toma de Rimbaud] é também o tempo da criação, da arte, o tempo em que o jovem sujeito tenta encontrar aquilo que de seu ser pode se traduzir à sua maneira [...] (LACADÉE, 2011, p. 161).

A escrita, o teatro, a música e a psicanálise são descritas como possibilidades concretas de devolver ao adolescente o "gosto pelas palavras" (LACADÉE, 2011, p. 161). Nesse caminho, a presença do outro adquire uma importância singular. O autor nos lembra de que é preciso que o outro possa escutar o adolescente em suas tentativas de recobrir com palavras “[...] a parte inominável revelada de seu ser [...]” (LACADÉE, 2011, p. 117). Nessa direção, nos apresenta uma série de situações em que dá destaque à intervenção desse outro que se encarna na figura de professores, diretores de teatro e cinema. Dessa forma, compreende-se como o educador, tanto quanto o psicanalista, pode vir a se constituir no que ele denomina "ponto de onde": uma posição singular capaz de acolher o sujeito adolescente, sem pressa e sem exigências excessivas, permitindo-lhe realizar essa transição 
traduzindo essa “[...] parte viva que o exilou de sua infância [...]” (LACADÉE, 2011, p. 117). A clareza com que o autor apresenta a função e importância desse outro, na difícil travessia a ser realizada pelos adolescentes, faz do livro leitura indispensável para quem se encontra envolvido, de alguma forma, com esses sujeitos.

Por fim, o autor reafirma a função da psicanálise como "[...] mais impossível que governar e educar [...]”, referindo-se à conhecida afirmação de Freud, pois está destinada a ocupar-se do que, posteriormente, Lacan nomeou como real, o que não funciona. Os jovens, ele nos lembra, estão sempre a apontar o que não funciona no mundo e, nesse ponto, suas ações e discursos não só se aproximam dos interesses da psicanálise como podem ser por ela acolhidos com precisão. Constatamos, ao final da leitura, que a proposta formulada no prefácio, de situar "em seu justo lugar" o real com que os adolescentes se veem confrontados, valendo-se da teoria psicanalítica, foi cumprida com precisão teórica e riqueza de exemplos. Acreditamos também que a leitura atenta da obra pode vir a produzir, no leitor, interessantes efeitos, tais como a revisão de antigas, e até mesmo preconceituosas concepções sobre adolescência; a compreensão da importância que adquire o outro para o adolescente nesse momento; a constatação da função da palavra inventada como guia nessa difícil travessia.

Valendo-se de um formato menos acadêmico, o que por vezes exige que o leitor se detenha e organize as ideias já apresentadas, a obra em questão, sem dúvida, faz avançar a discussão psicanalítica sobre a adolescência. Recuperando a questão formulada por Sônia Alberti, em Esse sujeito adolescente (1996, p. 35): "Se a adolescência não é um conceito psicanalítico, que a psicanálise pode dizer sobre ela?”, podemos responder, com Lacadée, que a psicanálise não só tem coisas a dizer mas que, principalmente, pode contribuir para transformar os modos de relação com o adolescente.

Independentemente do ponto em que cada um seja tocado pelo texto, o que é certo é que, de algum modo, ele será capaz de despertar o leitor para algum novo aspecto, alguma sutileza ainda não percebida dessa transição tão delicada. 


\section{REFERÊNCIAS}

ALBERTI, S. Esse Sujeito Adolescente. Rio de Janeiro: Relume-Dumará, 1996.

\section{NOTAS}

${ }^{1}$ Frank Wedekind (1864-1918) é autor, entre outras, dessa conhecida peça, O despertar da primavera (WEDEKIND, 1891), bastante reconhecida no meio psicanalítico. Foi comentada por Freud e teve sua tradução para o francês prefaciada por Lacan.

Recebido: 16/05/2012

Aprovado: 03/12/2012

Contato:

Pontifícia Universidade Católica Av. Dom José Gaspar, s/n, Coração Eucarístico

CEP 30535-901

Belo Horizonte, MG

Brasil 